\title{
Elderly Profile of Quality of Life Using WHOQOL-BREF Indonesian Version: A Community-Dwelling
}

\author{
Aghnia Rizki Hidayati, ${ }^{1}$ Sharon Gondodiputro, ${ }^{2}$ Lina Rahmiati ${ }^{2}$ \\ ${ }^{1}$ Diploma 4 of Midwifery Program Faculty of Medicine Universitas Padjadjaran, Indonesia \\ ${ }^{2}$ Department of Public Health Faculty of Medicine Universitas Padjadjaran, Indonesia
}

\begin{abstract}
Background: Indonesia as one of the developing countries is facing a demographic transition. The proportion of under-five children is decreasing while the proportion of elderly is rising. This situation is followed by the increase of noncommunicable/degenerative diseases. However, this situation is not a constraint for the elderly to have a better life. The WHOQOL Group had developed a questionnaire to measure the elderly's quality of life. The aim of this study was to describe the quality of life (QoL) of a community-dwelling elderly by using the WHOQOL-BREF questionnaire Indonesian version.

Methods: Eighty eight elderly from 6 villages in Jatinangor, West Java, Indonesia were involved in a descriptive study relating to QoL by using the WHOQOL-BREF questionnaire Indonesian version. The inclusion criteria were men and women, aged $\geq 60$ years, could communicate effectively, and had Mini Mental State Examination score $\geq>23$. The variables in the study were physical, psychological, social and environmental domains and facets in the QoL questionnaire. The collected data in the study were analyzed using the central tendency items.

Results: Most respondents had low QoL scores $(\leq 60)$. This study discovered that some facets of every domain in the WHOQOL-BREF had low scores, namely adequate energy, ability to perform daily living activities, satisfaction with work capacity, ability to concentrate, acceptance of physical appearance, satisfaction of sex life, financial fulfillment, availibility of information, opportunity for leisure activities and transport.

Conclusions: Most of the elderly have low QoL scores in some facets of every domain in the WHOQOL-BREF questionnaire.
\end{abstract}

Keywords: Elderly, environment domain, physical domain, psychological domain, social domain

\section{Introduction}

Indonesia, as a developing country, is facing a demographic transition. The demographic transition leads to decrease the under-five children proportion and raise the 60-andabove elderly proportion. Accordingly, this condition causes the proportion of the elderly population will be higher than the under-five children population. This condition is caused by the decrease of total fertility rate (TFR) and the raise of life expectancy. ${ }^{1}$ Based on the United Nations Population Fund (UNFPA) Indonesia, in 1971 the TFR in Indonesia was 5.6 and in 2035 the TFR will be decreasing to 1.9.1 In 1971, the life expectancy was 45.7 but it will be rising to approximately 72.4 in $2035 .{ }^{1}$

The rising of elderly population also generates changes in the population structure. The proportion of elderly aged 60-74 years tends to decrease while the proportion of elderly aged above 75 years tends to rise. ${ }^{1}$ Elderly population aged above 75 years will be approximately $21 \%$ among the total population in $2035 .^{1}$

Furthermore, demographic transition can cause epidemiological transition. Noncommunicable/degenerative diseases will mostly occur when compared to acute infectious diseases. ${ }^{2}$ Hence, this situation does not cause problems for the elderly to perform daily activities or to have a better life. Based on the World Health Organization (WHO), quality of life (QoL) is defined as "an individual's perceptions of their position in life in the context of the culture and value systems in which they live and in relation to their goals, expectations, standards and concerns". ${ }^{3}$ Quality of life is considered as an individual's subjective perceptions to their position in life which is not only associated with disease symptoms or diseases but also measurement

Correspondence: Aghnia Rizki Hidayati, Diploma 4 of Midwifery Program Faculty of Medicine, Universitas Padjadjaran, Jalan Raya Bandung-Sumedang Km.21, Jatinangor, Sumedang, Indonesia, Email: bidunpad.2014.021@gmail.com 
of disease impacts towards their QoL in daily activities. $^{3}$

Quality of life (WHOQOL-100 and WHOQOL-BREF) questionnaires had been provided by the WHOQOL Group in 1995 . $^{3}$ The questionnaires were translated into Indonesian in 2004 by experts, namely Ratna Mardiati, Satya Joewana, Hartati Kurniadi, Isfandari, and Riza Sarasvita. Additionally, the questionnaires had been revised twice (in 2014 and 2016) by Fredrick Dermawan Purba. The WHOQOL-BREF questionnaire includes 4 domains, namely physical, psychologycal, social relationships, and environment, consisting of 24 facets. ${ }^{3}$ A previous study by Salim et al. ${ }^{4}$ observed the WHOQOl-BREF validity and reliability for elderly in Indonesia.

The measurement of QoL has not been widely studied in Indonesia. The purpose of this study was to describe QoL in elderly using the Indonesian version of the WHOQOL-BREF questionnaire.

\section{Methods}

A descriptive study was carried out to 88 out of 97 elderly. The study was conducted in a suburb area near Bandung in June 2017. Located in Jatinangor, it is one of the sub-districts in Kabupaten Sumedang, West Java, Indonesia. The inclusion criteria were the elderly aged above 60 years, could communicate effectively, and did not have dementia through a measurement using the Mini Mental State Examination (MMSE) questionnaire scored $\geq 23$. The exclusion criterion in the study was the elderly who was absent during the study.

The study used multistage random sampling as the sampling method. Among 12 villages, 6 villages in Jatinangor sub-district were selected. The samples of each village were calculated based on the number of elderly in order to obtain the proportional total samples. Afterwards, one RW (Rukun Warga) of each village was selected by using the simple random sampling method. The respondents' selection was then performed by using consecutive sampling method.

The study commenced by describing the objectives of the study to the respondents. The respondents who agreed were asked to fill and sign the informed consent. Furthermore, the MMSE questionnaire test was carried out. If the MMSE score was $\geq 23$, the measurement of QoL would be performed by using the WHOQOL-BREF in Indonesian version.3 The questionnaire consisted of 26 questions which included 2 general questions relating to the respondents' perceptions to their QoL, satisfaction in life, and health condition; 4 domains such as the physical domain consists of 7 questions, psychologycal domain consists of 6 questions, social relationships domain consists of 3 questions, and environment domain consists of 8 questions. ${ }^{3}$ Every question scores from 1 to $5 .^{3}$ The total score of every domain was calculated, and transformed by using the transformation table with a scale $0-100 .{ }^{3}$ The total score of every domain was examined by using the Kosmogorov-Smirnov normality test. Since the data found in the study were not normally distributed $(p<0.05)$, the presented results were in the forms of median, mean, minimum, and maximum scores.

The respondents' characteristics were age, gender, marital status, and education level. The age characteristic was divided into two categories which were $60-69$ years and $\geq 70$ years. Gender was classified into man and woman, while marital status was divided into married and divorced/widower/widow. The education level was classified into 4 categories i.e. no education, primary school, junior school, and senior high school. The QoL level was classified into two categories which were good QoL scored $\geq 60$ and poor QoL scored $<60 .{ }^{5}$ The collected data in the study were presented in tables. Moreover, this study was approved by the Health Research Ethic Committee, Faculty of Medicine, Universitas Padjadjaran with the ethical number 779/ UN6.C.10/PN/2017.

\section{Results}

Among 88 respondents, the major respondents were those aged 60-69 years. The proportion between male and female respondents based on gender was slightly similar. Based on marital status, proportion of the respondents who were with or without spouses was slightly similar as well. The majority of the respondents showed lower education level but several of them were senior high school graduates (Table 1).

The study discovered that the QoL domains such as physical, psychologycal, social relationships, and environmental domains showed low scores $(<60)$. The results determined $100 \%$ of respondents had low physical domain score, $98.9 \%$ respondents had low psychological domain score, 96.6\% respondents had low social relationship domain score, and $89.8 \%$ respondents had 
Table 1 Respondents' Characteristics Distribution Based on Age, Gender, Marital Status, and Education Level

\begin{tabular}{lcc}
\hline \multicolumn{1}{c}{ Characteristics } & Frequency $(\mathbf{n}=\mathbf{8 8})$ & Percentage (\%) \\
\hline Age & $\mathbf{6 4}$ & $\mathbf{7 2 . 7}$ \\
60-69 years & 24 & 27.3 \\
$\geq 70$ years & & \\
Gender & 39 & 44.3 \\
Men & 49 & 55.7 \\
Women & & \\
Marital status & 43 & 48.9 \\
Divorced/widowed & 45 & 51.1 \\
Married/Spouses & & \\
Education level & 22 & 25 \\
No education & 45 & 51.1 \\
Primary school & 16 & 18.2 \\
Junior school & 5 & 5.7 \\
Senior high school & & \\
\end{tabular}

low environmental domain score.

The study also revealed that overall, the respondents perceived mediocre QoL. However, the respondents were satisfied with their health condition (Table 2). Based on the physical domain, most respondents revealed that they did not obtain satisfaction in their vitality (enough energy everyday), ability to perform daily living activities and their capacity to work. Based on the psychological domain, most respondents complained about the ability to concentrate and physical appearance. Based on social relationship domain, sex life was among the facets frequently complained by the respondents. Based on the environmental domain, financial fulfillment, availibility of information, opportunity for leisure activities and transport were the facets which mostly were complained by the respondents (Table 2).

\section{Discussions}

Aging is a multidimensional process of many changes6 related to cells and tissues generally caused by increased age. This condition leads to the increased risks of diseases and in many cases it can cause deaths. ${ }^{6}$ Nevertheless, aging is not a major problem for the elderly to improve their QoL. This study discovered that the respondents' QoL was low particularly the physical domain score.
This study revealed that most respondents were not satisfied with their physical performances such as did not have sufficient energy to perform daily activities (vitality), ability to perform daily living activities, and capacity to work. Lower vitality, daily living activity disturbances, and lower working capacity are several symptoms of fragility syndrome frequently found in elderly.7 According to Chen et al. ${ }^{7}$ fragility in elderly is the condition of the decreases of both physiological reserves and multiorgan system functions leading to increased vulnerability for adverse health outcomes. A previous study by Moreh et al. ${ }^{8}$ stated that fragility in elderly is commonly associated with immediate fatigue. Fatigue can increase along with increased age. Some factors which can influence fatigue are loneliness, depression, lower daily and physical activities, joint and back pains, lower sleep satisfaction, hypertension, and ischemic heart disease. ${ }^{8}$ Another study by Witard et al. ${ }^{9}$ reported that decreased muscular mass and strength are among several factors which can contribute to vitality in elderly.

Furthermore, cognitive impairments frequently occur in elderly which can influence daily functions. ${ }^{10}$ This study revealed that most respondents had concentration disturbances. Mild cognitive impairments often occur in elderly before having dementia although this condition may not disturb their daily living activities. ${ }^{11}$ Mild cognitive impairments if left 
Table 2 Scores of Each Facet and Domain

\begin{tabular}{|c|c|c|c|c|c|c|}
\hline \multirow{2}{*}{ No } & \multirow{2}{*}{ Domains } & \multirow{2}{*}{ Facets } & \multicolumn{4}{|c|}{ Score } \\
\hline & & & Median & Mode & Minimum & Maximum \\
\hline 1 & & $\begin{array}{l}\text { How would you rate your quality of } \\
\text { life? }\end{array}$ & 3 & 3 & 2 & 5 \\
\hline 2 & & $\begin{array}{l}\text { How satisfied are you with your } \\
\text { health? }\end{array}$ & 3 & 3 & 2 & 4 \\
\hline 3 & Physical & $\begin{array}{l}\text { To what extent do you feel that } \\
\text { physical pain prevents you from doing } \\
\text { what you need to do? }\end{array}$ & 3 & 3 & 2 & 5 \\
\hline 4 & & $\begin{array}{l}\text { How much do you need any medical } \\
\text { treatment to function in your daily life? }\end{array}$ & 3 & 3 & 2 & 4 \\
\hline 5 & & $\begin{array}{l}\text { Do you have enough energy for } \\
\text { everyday life? }\end{array}$ & 2 & 2 & 1 & 4 \\
\hline 6 & & How well are you able to get around? & 3 & 3 & 2 & 4 \\
\hline 7 & & How satisfied are you with your sleep? & 3 & 3 & 1 & 4 \\
\hline 8 & & $\begin{array}{l}\text { How satisfied are you with your ability } \\
\text { to perform your daily living activities? }\end{array}$ & 2 & 2 & 1 & 4 \\
\hline 9 & & $\begin{array}{l}\text { How satisfied are you with your } \\
\text { capacity for work? }\end{array}$ & 2 & 2 & 1 & 4 \\
\hline 10 & Psychological & How much do you enjoy life? & 3 & 3 & 2 & 4 \\
\hline 11 & & $\begin{array}{l}\text { To what extent do you feel your life to } \\
\text { be meaningful? }\end{array}$ & 3 & 3 & 2 & 5 \\
\hline 12 & & How well are you able to concentrate? & 2 & 2 & 1 & 4 \\
\hline 13 & & $\begin{array}{l}\text { Are you able to accept your physical } \\
\text { appearance? }\end{array}$ & 2 & 2 & 1 & 5 \\
\hline 14 & & How satisfied are you with yourself? & 3 & 3 & 2 & 5 \\
\hline 15 & & $\begin{array}{l}\text { How often do you have negative } \\
\text { feelings such as blue mood, despair, } \\
\text { anxiety, depression? }\end{array}$ & 4 & 4 & 2 & 5 \\
\hline 16 & Social Relationship & $\begin{array}{l}\text { How satisfied are you with your } \\
\text { personal relationships? }\end{array}$ & 3 & 3 & 2 & 4 \\
\hline 17 & & $\begin{array}{l}\text { How satisfied are you with your sex } \\
\text { life? }\end{array}$ & 2 & 2 & 1 & 4 \\
\hline 18 & & $\begin{array}{l}\text { How satisfied are you with the support } \\
\text { you get from your friends? }\end{array}$ & 3 & 3 & 2 & 4 \\
\hline 19 & Environment & How safe do you feel in your daily life? & 3 & 3 & 2 & 5 \\
\hline 20 & & $\begin{array}{l}\text { How healthy is your physical } \\
\text { environment? }\end{array}$ & 3 & 3 & 1 & 4 \\
\hline 21 & & $\begin{array}{l}\text { Have you enough money to meet your } \\
\text { needs? }\end{array}$ & 2 & 2 & 1 & 4 \\
\hline 22 & & $\begin{array}{l}\text { How is the availability of information } \\
\text { that you need in your day-to-day life? }\end{array}$ & 2 & 2 & 1 & 4 \\
\hline 23 & & $\begin{array}{l}\text { To what extent do you have the } \\
\text { opportunity for leisure activities? }\end{array}$ & 2 & 2 & 1 & 4 \\
\hline 24 & & $\begin{array}{l}\text { How satisfied are you with the } \\
\text { conditions of your living place? }\end{array}$ & 3 & 2 & 2 & 4 \\
\hline 25 & & $\begin{array}{l}\text { How satisfied are you with your access } \\
\text { to health services? }\end{array}$ & 3 & 3 & 1 & 5 \\
\hline 26 & & $\begin{array}{l}\text { How satisfied are you with your } \\
\text { transport? }\end{array}$ & 2 & 2 & 1 & 5 \\
\hline
\end{tabular}


untreated, will be a public health problem in the future. ${ }^{11}$

Moreover, this study discovered a unique finding that most respondents did not accept physical appearance changes. A previous study explained that physical appearances are related to self-esteem although there may be differences based on age and gender. ${ }^{12}$ Selfesteem in elderly men is influenced by general physical appearances which they cannot reach. Meanwhile, the major predictor of self-esteem in elderly women is overweight. ${ }^{12} \mathrm{~A}$ study by Tavarez et al. ${ }^{13}$ reported that lower self-esteem can contribute to physical conditions and lower social participations.

According to Ambler et al. ${ }^{14}$ sex life in elderly men and women becomes a main component of psychological and physical intimacy. Increased age does not mean sex life is not important. Desire to be close with someone and sexual contacts occur in lifetime.15,16 Generally, elderly are unwilling to complain about sex life. ${ }^{16}$ This condition leads to undetected and unreported sexual problems. ${ }^{16}$ Elderly patients did not always complain relating to sexual dysfunctions to the doctors. ${ }^{16}$ Approximately $92 \%$ men and $96 \%$ women, who had at least one sexual complaint, did not seek treatment. This study discovered that sex life was mostly complained by the respondents. This condition occurred because there were respondents who did not have a spouse, and those who had a spouse potentially felt ashamed to express satisfaction or dissatisfaction regarding their sex life.

Additionally, this study discovered that most respondents had financial problems. A study revealed that Indonesia as a developing country is not widely establishing old-age insurance leading to the condition that most elderly lived depending on their families. ${ }^{2}$ The Indonesian Central Statistics Agency reported, the number of elderly dependent on their families were rising for years, particularly in the rural areas. ${ }^{17}$ In 2012 , the number of elderly dependent on their families in rural area was $14.09 \%$ which increased continuously to $15.04 \%$ in $2016 .{ }^{17}$ Afterwards, $44.59 \%$ of elderly were included in the category of $40 \%$ of the population with low economic status; the percentage of elderly women was higher than elderly men $(46.04 \%$ compared to $42.97 \%) .{ }^{17}$ This condition determines that elderly women are vulnerable to have financial problems when compared to elderly men.

Everybody needs information in their lives, including the elderly. This study discovered that some elderly complained about the availability of information relating to daily living. However, investigation regarding to information necessity in elderly has not been widely studied. Hence, a study conducted in Nigeria by Edewor et al. ${ }^{18}$ discovered some respondents need information relating to their health and financial/pension conditions.

Furthermore, this study discovered less opportunity for leisure activities in elderly. Recreation activities play an important role to improve QoL in elderly. A study reported that the elderly who usually do recreation activities have better mental health because recreation activities can also decrease stress, depression, anxiety and improve health and fitness. ${ }^{19}$ Recreation activities increase social participation for elderly in the society leading to positive effects for health.,19 According to $\operatorname{Villar}^{20}$, the elderly who succeed in living are influenced by two components i.e. the opportunity to participate in the society (social participations) and ability to participate. Recreation activities are positive efforts for elderly to reach successful aging.

There were several limitations in this study as most respondents had lower education level which caused the respondents did not properly comprehend the questions. Moreover, the study only described elderly' perceptions to the questions included in the WHOQOLBREF questionnaire which should be explored further regarding the reasons for choosing a certain score on the questions. This should be performed in order to discover detailed descriptions relating to QoL in elderly.

The study concluded that the QoL in elderly is low. The most caused facets of dissatisfactions in elderly were vitality, ability to do daily living activities, capacity of working, ability to concentrate, acceptance of physical appearances, sex life, financial fulfillment, information availibility, opportunity for leisure activities, and transportation.

\section{References}

1. UNFPA Indonesia. Indonesia on the threshold of population ageing. 1st ed. Jakarta: UNFPA Indonesia; 2014.

2. Cao J, Rammohan A. Social capital and healthy ageing in Indonesia. BMC Public Health. 2016;16(631):1-14.

3. World Health Oranization. WHOQOL-BREF, introduction, administration, scoring and generic version of the assessment. $1^{\text {st }} \mathrm{ed}$. Geneva: WHO; 1996.

4. Salim OC, Sudharma NI, Kusumaratna RK, Hidayat A. Validitas dan reliabilitas World 
Health Organization Quality Of Life-BREF untuk mengukur QoL lanjut usia. Universa Medicina. 2007;26(1):27-38.

5. Silva PAB, Soares SM, Santos JFG, Silva LB. Cut-off point for WHOQOL-BREF as a measure of quality of life of older adults. Rev Saúde Pública. 2014;48(3):390-7.

6. Amarya S, Singh K, Sabharwal M.Changes during aging and their association with malnutrition. Journal of Clinical Gerontology \& Geriatrics.2015;60:78-84.

7. Chen $X$, Mao G, Leng SX. Frailty syndrome: an overview. Clin Interv Aging. 2014;9(3):433-41.

8. Moreh E, Jacob JM, Stessman J. Fatigue, function, and mortality in older adults. J Gerontol A Biol Sci Med Sci. 2010;65(8):887-95.

9. Witard OC, McGlory C, Hamilton DL, Phillips,SM. Growing older with health and vitality: a nexus of physical activity, exercise and nutrition. Biogerontol. 2016;17(5):529-46.

10. Dregan A, Stewart R, Gulliford MC. Cardiovascular risk factors and cognitive decline in adults aged 50 and over: a population-based cohort study. Age and Ageing. 2013;42(3):338-45.

11. Geda YE. Mild cognitive impairment in older adults. Curr Psychiatry Rep. 2012; 14(4):320-27.

12. Baker L, Gringar E. Body image and selfesteem in older adulthood. Ageing and
Society. 2009;29(7):977-95.

13. Tavares DMdS, Matias TGC, Ferreira, PCdS, Pegorari MS, Nasciment JS, de Paiva MM. Quality of life and self-esteem among the elderly in the community. Ciencia \& saude coletiva. 2016;21(11):3557-64.

14. Ambler DR, Bieber EJ, Diamond MP. Sexual function in elderly women: a review of current literature. Rev Obstet Gynecol. 2012;5(1):16-27.

15. Rheaume C, Mitty E. Sexuality and intimacy in older adults. Geriatric Nursing. 2008;29(5):342-9.

16. Omole F, Fresh EM, Sow C, Lin J, Taiwo B, Nichols M. How to discuss sex with elderly patients. The Journal of Family Practice. 2014;63(4):E1-4.

17. Badan Pusat Statistik. Statistik penduduk lanjut usia. Jakarta: BPS; 2016.

18. Edewor N, Ijiekhuamhen OP, Emekaukwu UP. Elderly people and their information needs. Library Philosophy and Practice (e-journal) [serial on the internet]. 2016 Feb [cited 2017 Dec 20];2016(1332):[about 16p.]. Available from: http://digitalcommons.unl.edu/ libphilprac/1332.

19. Singh B, Kir UV. Recreational activities for senior citizens. IOSR J Human Soc Sci. 2014;19(4):24-30.

20. Villar F.Successful ageing and development: the contribution of generativity in older age. Ageing Soc. 2012;32(7):1087-105. 